\title{
ע Lukiolaisten masentuneisuus ja vanhempien työllisyystilanne - Uudenmaan ja Pohjanmaan maakuntien suomen- ja ruotsinkielisten lukioiden opiskelijoiden vertailua
}

Suomessa väestöryhmien väliset hyvinvointierot ovat suuria. Tutkimuksissa on raportoitu esimerkiksi alueellisia, sosioekonomisten ryhmien välisiä ja suomen- ja ruotsinkielisen kieliryhmän välisiä hyvinvointieroja. Nämä erot näkyvät myös lasten ja nuorten terveydessä ja hyvinvoinnissa.

Tässä tutkimuksessa analysoitiin, vaihteleeko Uudenmaan ja Pohjanmaan lukiolaisten masentuneisuuden yleisyys lukion opetuskielen, sukupuolen, maakunnan ja vanhempien työllisyystilanteen suhteen. Aineistona olivat vuosina 2010 ja 2011 Kouluterveyskyselyihin (Terveyden ja hyvinvoinnin laitos) vastanneet Uudenmaan ja Pohjanmaan alueilla sijaitsevien lukioiden oppilaat $(n=3974)$. Masentuneisuutta mitattiin Kouluterveyskyselyyn sisältyvällä Beckin lyhyen mielialakyselyn suomalaisella versiolla, joka mittaa vastaajan itse arvioimaa masennusoireilua.

Uudenmaan ja Pohjanmaan lukiolaisista II \%:lla oli keskivaikeaa tai vaikeaa masentuneisuutta. Kieliryhmien välinen ero masentuneisuuden esiintyvyydessä ilmeni ainoastaan Uudellamaalla, jossa keskivaikea tai vaikea masentuneisuus oli suomenkielisten lukioiden opiskelijoilla yleisempää kuin ruotsinkielisten lukioiden opiskelijoilla.

Keskeisin tulos oli se, että suomenkielisten lukioiden opiskelijoilla vanhempien työttömyys tai pakkoloma lisäsivät selvästi keskivaikean tai vaikean masentuneisuuden riskiä. Jos toinen vanhemmista oli työttömänä tai pakkolomalla, masentuneisuuden todennäköisyys oli kaksin kertainen (Ristitulosuhde $O R=2,04 ; 95 \%$ luottamusväli I,52-2,74) ja jos molemmat vanhemmista olivat työttömänä tai pakkolomalla, masentuneisuuden todennäköisyys oli yli viisin kertainen (Ristitulosuhde OR $=5,10 ; 95 \%$ luottamusväli 2,88-9,03) verrattuna lukiolaisiin, joiden vanhemmilla ei ollut työttömyyttä tai pakkolomia. Ruotsinkielisten lukioiden opiskelijoilla vanhempien työttömyys tai pakkoloma ei ollut yhteydessä keskivaikean tai vaikean masentuneisuuden riskiin.

Voidaan pohtia, miksi suomenkielisen ja ruotsinkielisen kieliryhmän välillä on eroja tarkasteltaessa lukiolaisten masentuneisuutta vanhempien työttömyyden tai pakkolomien suhteen. Voidaanko tätä eroa selittää esimerkiksi muuttoliikkeen vaikutuksen tai perheiden taloudellisen toimeentulon kautta.

Asiasanat: Lukiolaiset, masentuneisuus, kieliryhmät, vanhempien työllisyystilanne ELINA KANGAS, JORMA TYNJÄLÄ, RAILI VÄLIMAA, HANNE KIVIMÄKI 


\section{JOHDANTO}

Suomalaisten nuorten psyykkinen pahoinvointi ja erityisesti masennusoireilu on ollut viime aikoina usein yhteiskunnallisen keskustelun kohteena. On pohdittu ongelman laajuutta ja moninaisuutta. Tässä artikkelissa tarkastellaan lukiolaisten masentuneisuuden yleisyyttä ja vanhempien työllisyystilannetta. Uudenmaan ja Pohjanmaan lukioiden suomen- ja ruotsinkielisiä opiskelijoita vertaillaan käyttäen aineistona Terveyden ja hyvinvoinnin laitoksen Kouluterveyskyselyjä vuosilta 2010 ja 2011.

Suomessa väestöryhmien väliset terveys- ja hyvinvointierot ovat suuria. Tutkimuksissa on raportoitu esimerkiksi alueellisia hyvinvointieroja (1), sosioekonomisten ryhmien välisiä hyvinvointieroja (2) ja suomen- ja ruotsinkielisen kieliryhmän välisiä hyvinvointieroja $(3,4,5)$.

Alueellisia hyvinvointieroja tarkasteltaessa ilmenee, että Suomessa hyvinvoivat kunnat sijoittuvat erityisesti länsi- ja etelärannikolle eli alueille, jossa asuu ruotsinkielistä väestöä. Rannikkoseudun ruotsinkieliset alueet ovat jo 1950luvun Suomessa olleet keskimääräistä korkeamman hyvinvoinnin aluetta (6). Viime vuosikymmeninä 1990-luvulta 2000-luvulle tapahtui muutos, ja hyvinvoivien kuntien ryhmä keskittyi aiempaakin selvemmin rannikkoseudulle kuntiin, joissa asuu ruotsinkielistä väestöä (1). Tähän tutkimukseen valitut Uudenmaan ja Pohjanmaan kunnat sijoittuvat siis keskimääräistä korkeamman hyvinvoinnin alueelle.

Suomen- ja ruotsinkielisten kieliryhmien välinen ero hyvinvoinnissa tulee esille tarkasteltaessa esimerkiksi kuolleisuutta, sairastavuutta, oireilua ja itsearvioitua terveyttä. Ruotsinkielisten miesten elinajanodote on noin kolme vuotta suomenkielisiä miehiä pitempi ja ruotsinkielisten naisten elinajanodote on reilu vuosi pitempi kuin suomenkielisten naisten. Kieliryhmien väliset kuolleisuuserot vaihtelevat kuitenkin alueittain. Ero on pieni Turun ja Porin seudulla sekä Uudellamaalla, mutta selvästi suurempi Helsingissä ja Vaasassa. (7) Kieliryhmien väliset erot ilmenevät myös nuorten ja nuorten aikuisten itsemurhakuolleisuudessa. Pohjanmaan ja Uudenmaan rannikkoseudun 15-30-vuotiailla asukkailla itsemurhat ovat suomenkielisillä kaksi kertaa ruotsinkielisiä yleisempiä. Sen sijaan kieliryhmien välillä ei ole eroa tarkasteltaessa muita ulkoisia kuoleman syitä, esimerkiksi onnettomuuksia. (8)
Itsemurhat ovat usein yhteydessä masennukseen ja muihin mielenterveyden ongelmiin (9). Ruotsinkielisillä onkin suomenkielisiä vähemmän mielenterveyden häiriöitä, lukuun ottamatta vakavia psykooseja (10). Ruotsinkielisillä esiintyy vähemmän esimerkiksi masennusta ja surumielisyyttä, väsymystä ja heikkouden tunnetta, ylirasittuneisuutta, ärtyneisyyttä, hermostuneisuutta ja alkoholiongelmia (11).

Kieliryhmien väliset erot ilmenevät myös tarkasteltaessa somaattista sairastavuutta ja itsearvioitua terveyttä. Ruotsinkieliset sairastavat suomenkielisiä vähemmän esimerkiksi sydän- ja verisuonisairauksia (10). Itsearvioitu fyysinen ja psyykkinen terveys ovat parempia ruotsinkielisillä $(3,5)$.

Suomen- ja ruotsinkielisten lasten ja nuorten terveyseroja on tutkittu aikuisväestöä vähemmän. Ruotsinkielisillä koululaisilla koettu oireilu on vähäisempää (12) ja koettu terveys on parempi $(12,13)$. Saarelan ja Finnäsin (14) tutkimuksen mukaan ruotsinkielisten koululaisten terveys on parempi objektiivisilla eli lääketieteellisiin diagnooseihin perustuvilla terveysmittareilla mitattaessa, mutta eroa ei tässä tutkimuksessa tullut esiin koetussa terveydessä.

WHO-Koululaistutkimuksen mukaan suomenkielisten koulujen oppilaat kokivat yleisemmin masentuneisuutta kuin ruotsinkielisten koulujen oppilaat. Kummassakin kieliryhmässä tytöt kokivat masentuneisuutta poikia yleisemmin. (12) Vuosien 2007 ja 2008 THL:n Kouluterveysaineistoon perustuvassa tutkimuksessa tarkasteltiin Uudenmaan ja Pohjanmaan kuntien lukiolaisten masentuneisuutta kieliryhmittäin. Suomenkielisten lukioiden opiskelijoilla keski vaikea tai vaikea masentuneisuus oli yleisempää kuin ruotsinkielisten lukioiden opiskelijoilla. Maakunnittain tarkasteltaessa tällainen kieliryhmien välinen ero masentuneisuuden esiintyvyydessä ilmeni ainoastaan Uudellamaalla. (15)

Pohjoismaissa perheiden sosioekonomiset erot muodostavat eriarvoisuutta nuorten hyvinvointiin, kun mittareina käytetään vanhempien koulutusta, ammattia, työllisyystilannetta ja perheen tulotasoa. Matalaan sosioekonomiseen asemaan kuuluvien perheiden nuorilla esiintyy muita yleisemmin oireilua, kroonisia sairauksia ja hidasta pituuskasvua. (16)

Työttömyysasteella on merkitystä siihen, millä tavalla vanhempien työelämän ulkopuolella 
oleminen vaikuttaa lasten hyvinvointiin. Pohjoismaalaisia perheitä tarkasteltaessa on havaittu, että vuonna 1984 lapset voivat huonommin niissä perheissä, joissa vähintään toinen vanhemmista oli työssä kuin niissä perheissä, joissa molemmat vanhemmat olivat ilman työtä. Vuonna 1996 (laman aikana) suhde kääntyi niin, että huonoimmin voivat ne lapset, joiden vanhemmat olivat työelämän ulkopuolella. Tutkijat tulkitsivat, että matalan työttömyysasteen ajankohtana vanhemmat saattavat vapaaehtoisesti valita työelämän ulkopuolelle jäämisen ja esimerkiksi lasten hoitamisen kotona. Korkean työttömyysasteen aikana vanhemmat ovat usein pakotettuja jäämään pois työelämästä. Tutkijat pohtivat myös sitä, että korkean työttömyysasteen aikana valtion sosiaaliset tukitoimet perheille heikkenivät. (17)

Myös suomalaisesta tutkimuksesta ilmenee, että 1990-luvun alkupuolen laman aikainen vanhempien työttömyys oli riski suomalaisten varhaisnuorten mielenterveydelle. Nuoren mielenterveyden heikkenemiseen vaikuttivat työttömyyden perheelle aiheuttamat taloudelliset paineet, jotka vaikuttivat vanhempien mielenterveyteen, parisuhteen vuorovaikutukseen ja vanhemmuuden laatuun. (18)

Edellä mainittuja tutkimustuloksia $(17,18)$ vahvistavat monet suomalaiset tutkimukset, jotka osoittavat, että vanhempien työllisyystilanne on yhteydessä nuorten hyvinvointiin. Nuorilla, joiden vanhemmista enintään toinen käy työssä, riski huonoksi koettuun terveyteen, viikoittaisiin oireisiin, ylipainoon ja mielenterveyspalvelujen käyttöön oli suurempi kuin nuorilla, joiden molemmat vanhemmat ovat työssä (19). Sekä vanhemman työttömyys että nuoren kokemus taloudellisista vaikeuksista lisäsivät masennuksen riskiä tytöillä ja pojilla (20). Suomalaisten 14-16-vuotiaiden nuorten masentuneisuutta on tutkittu perheiden sosioekonomisten ryhmien mukaan vuodesta 2000 vuoteen 2011. Vaikean masentuneisuuden esiintyvyys oli lähes kaksinkertaista niillä nuorilla (sekä tytöillä että pojilla), joilla vanhemmat olivat työttöminä ja matalasti koulutettuja verrattuna perheisiin, joissa vanhemmat kävivät työssä ja heillä oli korkea koulutus. Tämä sosioekonomisten ryhmien välinen ero nuorten vaikean masentuneisuuden esiintyvyydessä säilyi koko kymmenvuotisen tutkimusperiodin ajan. (21) Kaltiala-Heinon ym.
(22) tutkimuksen mukaan kuitenkin vain pojilla toisen tai molempien vanhempien työttömyys oli yhteydessä masennusoireiluun.

Yhteenvetona voidaan todeta, että perheen sosioekonomisella asemalla on yhteys nuorten psyykkiseen hyvinvointiin, esimerkiksi masentuneisuuteen. Lisäksi tutkimukset osoittavat suomen- ja ruotsinkielisten kieliryhmien välisiä eroja nuorten masennusoireilussa. Sen sijaan vähemmän on tutkimustietoa siitä, onko perheen sosioekonomisen aseman yhteys nuorten masentuneisuuteen samanlainen molemmissa kieliryhmissä.

Masentuneisuuden ja masennusoireilun käsitteillä viitataan tässä artikkelissa itsearvioituun mielentilaan. Masennuksella sen sijaan tarkoitetaan kliinisesti diagnosoitua sairautta. (22) Riski sairastua masennukseen kasvaa voimakkaasti murrosiän käynnistymisen jälkeen ja tytöillä masennusriski on kaksinkertainen poikiin verrattuna. Eniten uusia masennusjaksoja ilmaantuu 15-18-vuotiaiden ikäryhmässä eli lukioikäisenä. (23) Suomalaisista lukiolaisista joka kymmenes kokee keskivaikeaa tai vaikeaa masentuneisuutta, pojista $7 \%$ ja tytöistä $13 \%(24)$.

Lievempi masennusoireilu (masentuneisuus), joka ei täytä kaikkia kliinisen masennustilan diagnostisia kriteereitä, on vakava ongelma nuoren mielenterveydelle. Se voi vaikeuttaa nuoren psyykkistä, sosiaalista ja fyysistä kehitystä monin tavoin $(25,26,27,28)$. Myös nuorten lievemmillä masennusoireilla, jotka eivät täytä vakavan masennuksen diagnostisia kriteereitä, on usein vaikutusta nuoren myöhempiin elämänvaiheisiin: lievät masennusoireet nuoruudessa voivat ennustaa myöhemmin kehittyvää kliinistä masennustilaa $(25,26)$, samanaikaissairastamista (myös muu mielenterveydehäiriö), alentunutta toimintakykyä ja päihteiden väärinkäyttöä (26). Siksi nuorten mielenterveyden ongelmat ovat haaste yhteiskunnalle ja terveyden edistämiselle.

Tämän tutkimuksen tavoitteena on vertailla, miten Uudenmaan ja Pohjanmaan lukioiden opiskelijoiden masentuneisuuden yleisyys vaihtelee lukion opetuskielen, maakunnan ja sukupuolen suhteen. Lisäksi tarkastellaan, miten Uudenmaan ja Pohjanmaan lukioiden opiskelijoiden masentuneisuuden yleisyys vaihtelee vanhempien työllisyystilanteen suhteen ja onko vaihtelussa kieliryhmien, maakuntien ja sukupuolten välisiä eroja. 


\section{AINEISTO JA MENETELMÄT}

\section{TUTKIMUSAINEISTO}

Tutkimus perustuu vuosien 2010 ja 2011 Terveyden ja hyvinvoinnin laitoksen Kouluterveyskyselyn aineistoon. Kouluterveyskysely tehdään kaikkien lukioiden 1. ja 2. vuosikursseilla. Lisäksi kysely tehdään peruskoulujen 8 . ja 9. luokilla sekä ammatillisten oppilaitosten 1. ja 2. vuosikursseilla. Parillisina vuosina kyselyyn osallistuivat Etelä-Suomen, Itä-Suomen ja Lapin läänien kunnat ja parittomina vuosina Länsi-Suomen ja Oulun läänien sekä Ahvenanmaan kunnat. (29)

Tutkimuksen perusjoukko oli Pohjanmaan maakunnan ja Kokkolan lukioiden 1. ja 2. vuosikurssin opiskelijat vuonna 2011 sekä Uudenmaan kuntien (Hanko, Kirkkonummi, Lohja, Mäntsälä ja Raasepori) ja Itä-Uudenmaan maakunnan lukioiden 1. ja 2. vuosikurssin opiskelijat vuonna 2010. Lukion 1. ja 2. vuosikurssin opiskelijoita tarkasteltiin yhtenä kokonaisuutena. Uudenmaan ja Pohjanmaan alueella sijaitsevien kuntien valitseminen tutkimusaineistoon mahdollisti suomenkielisten ja ruotsinkielisten lukioiden opiskelijoiden vertaamisen.

Tässä tutkimuksessa viitataan Pohjanmaan maakuntaan ja Kokkolaan Pohjanmaa-nimellä ja Uudenmaan ja Itä-Uudenmaan maakuntiin Uusimaa-nimellä.

Vastanneita oli 3974 opiskelijaa, joista tyttöjä oli 2272 ja poikia oli 1702. Suomenkielisten lukioiden opiskelijoita oli 2147 ja ruotsinkielisten 1827. Vastanneista oli 1899 Uudenmaan ja 2075 Pohjanmaan lukioiden opiskelijoita. Viimeksi kuluneen vuoden aikana 2981 opiskelijan vanhemmista kumpikaan ei ollut työttömänä tai pakkolomalla, 879 opiskelijan vanhemmista toinen oli työttömänä tai pakkolomalla ja 100 opiskelijalla molemmat vanhemmat olivat työttömänä tai pakkolomalla.

Kieliryhmittäinen tarkastelu tehtiin koulun opetuskielen mukaan. Kyselylomakkeet lähetettiin koulun opetuskielen mukaisesti joko suomentai ruotsinkielisinä. Tästä syystä lomakkeen kieli ei välttämättä kerro vastaajan äidinkielestä.

Suomenkielisissä lukioissa 1572 opiskelijan vanhemmista kumpikaan ei ollut työttömänä tai pakkolomalla, 505 opiskelijan vanhemmista toinen oli työttömänä tai pakkolomalla ja 62 opiskelijalla molemmat vanhemmat olivat työt- tömänä tai pakkolomalla. Ruotsinkielisissä lukioissa 1409 opiskelijan vanhemmista kumpikaan ei ollut työttömänä tai pakkolomalla, 374 opiskelijan vanhemmista toinen oli työttömänä tai pakkolomalla ja 38 opiskelijalla molemmat vanhemmat olivat työttömänä tai pakkolomalla.

\section{MITTARIT}

Lukiolaisten masennusoireilun esiintyvyyttä tarkasteltiin käyttäen mittarina Kouluterveyskyselyyn sisältynyttä Beckin lyhyen mielialakyselyn 13-osaista suomalaista versiota, joka mittaa vastaajan itse arvioimaa masennusoireilua.

Suomalaisessa versiossa Beckin lyhyestä mielialakyselystä (ks. 30-33) on samat kysymykset kuin Beckin alkuperäisessä lyhyessä kyselyssä (ks. 34,35), mutta alkuperäisiin vastausvaihtoehtoihin on lisätty ensimmäiseksi vaihtoehdoksi positiivista mielialaa kuvaava vastausvaihtoehto. Kysely sisältää kysymyksiä vastaajan mielialasta, suhtautumisesta tulevaisuuteen ja menneisyyteen, tyytyväisyydestä omaan elämään, käsityksistä omasta itsestä, suhtautumisesta vieraisiin ihmisiin, kyvystä päätösten tekoon, väsymyksestä, uupumuksesta, nukkumisesta ja ruokahalusta. (31, 33) Mittarissa pyydetään nuorta vastaamaan kysymyksiin liittyen mielialan erilaisiin piirteisiin. Masennusoireiden esiintyvyyden lisäksi sen avulla voidaan tarkastella masentuneisuuden vaikeusastetta. (33)

Kouluterveyskyselyn sisältämistä Beckin mielialakyselyn suomalaisen version kysymyksistä muodostuu summamuuttuja. Jokaiselle vastaajalle lasketaan yksilöllinen masentuneisuutta osoittava summapistemäärä, jonka avulla voidaan tarkastella yksilön masentuneisuuden voimakkuutta. Summapistemäärä lasketaan niin, että kunkin kysymyksen vastausvaihtoehdot 1 ja 2 saavat arvon 0 , vastausvaihtoehto 3 saa arvon 1, vastausvaihtoehto 4 arvon 2 ja vastausvaihtoehto 5 arvon 3 . Summapistemäärä vaihtelee välillä 0-39. Masentuneisuuden vaikeusaste luokitellaan siten, että pisteet 0-4 tarkoittavat, että masentuneisuutta $e i$ ole tai se on erittäin lievä, pisteet 5-7 merkitsevät lievää masentuneisuutta, pisteet 8-15 keskivaikeaa masentuneisuutta ja yli 15 menevät pisteet kertovat vaikeasta masentuneisuudesta. (33)

Tässä tutkimuksessa masentuneisuutta tarkasteltiin kaksiluokkaisena muuttujana. Masen- 
tuneisuusmuuttuja luokiteltiin niin, että ei ja lievä masentuneisuus yhdistettiin yhdeksi luokaksi ja keskivaikea ja vaikea masentuneisuus yhdistettiin yhdeksi luokaksi. Tällaista kaksiluokkaista masentuneisuusmuuttujaa (ei/lievä masentuneisuus - keskivaikealvaikea masentuneisuus) on käytetty useissa muissakin Kouluterveyskyselyyn pohjautuvissa tutkimuksissa (esim. 36, 37). Tällaista kaksiluokkaista luokittelua voidaan perustella myös sillä, että nuoria, jotka saavuttavat Beckin lyhyessä mielialakyselyssä vähintään keskivaikean masentuneisuuden pistemäärän, on syytä tarkastella masentuneisuuden vuoksi erityistä huomiota vaativana, kliinisen masennuksen riskiryhmänä (32). Lievän masentuneisuuden pistemäärän saaneiden ei sen sijaan katsota kuuluvan kliinisen masennuksen riskiryhmään, koska nuoruusikään kuuluu normaalina osana tietty mielialanvaihtelu ja surumielisyys.

Lukiolaisten vanhempien viimeksi kuluneen vuoden aikaista työllisyystilannetta mitattiin Kouluterveyskyselyn kysymyksellä Ovatko vanhempasi olleet viimeksi kuluneen vuoden aikana työttöminä tai pakkolomalla? Vastausvaihtoehdot olivat ei kumpikaan, toinen vanhemmista ja molemmat vanhemmat.

\section{TILASTOLLISET ANALYYSIMENETELMÄT}

Aineiston tilastollisessa analyysissä käytettiin ristiintaulukointia ja binääristä logistista regressioanalyysia. Ristiintaulukoinnin avulla tutkittiin masentuneisuuden jakaumien eroja taustamuuttujien eli vanhempien työttömyyden tai pakkoloman, kieliryh-mien, maakuntien ja sukupuolten suhteen. Muuttujien välistä tilastollista merkitsevyyttä tarkasteltiin $\chi^{2}$-riippumattomuustestillä.

Binäärisen logistisen regressioanalyysin avulla tarkasteltiin lukiolaisten vanhempien työttömyyden tai pakkolomien, kielen, sukupuolen ja maakunnan yhteyttä masentuneisuuteen. Logistisessa regressioanalyysissa muuttujien vaikutuksen voimakkuutta kuvataan ristitulosuhteen (OR) avulla. OR-luvuille laskettiin $95 \%$ :n luottamusvälit. Tilastollisen merkitsevyyden raja-arvona käytettiin $\mathrm{p}<0,05$. Tilastolliset analyysit tehtiin IBM SPSS Statistics 19-ohjelmalla.

\section{TULOKSET}

\section{MASENTUNEISUUDEN ESIINTYYYYS UUDENMAAN JA POHJANMAAN LUKIOLAISILLA}

Uudellamaalla (12\%) lukiolaisten keskivaikea tai vaikea masentuneisuus oli hieman yleisempää kuin Pohjanmaalla $(10 \%) \quad(p=0,044)$. Tytöillä $(13 \%)$ keskivaikea tai vaikea masentuneisuus oli yleisempää kuin pojilla $(8 \%) \quad(\mathrm{p}<0,001)$. Koko aineistoa tarkasteltaessa suomenkielisten ja ruotsinkielisten lukioiden opiskelijoiden välillä ei ilmennyt eroa masentuneisuuden esiintyvyydessä. (Taulukko 1.)

Taulukko 1. Selittävien muuttujien (kieliryhmä, sukupuoli, maakunta ja vanhempien työllisyystilanne) jakaumat lukiolaisten masentuneisuuden vaikeusasteen mukaan $(\%, \mathrm{n})$. THL:n Kouluterveyskysely 2010/2011.

\begin{tabular}{|c|c|c|c|c|c|c|c|c|c|c|}
\hline \multirow[t]{2}{*}{$\begin{array}{l}\text { Masentu- } \\
\text { neisuus }\end{array}$} & \multirow{2}{*}{$\begin{array}{r}\text { Kaikki } \\
\\
\\
\% \\
\end{array}$} & \multirow{2}{*}{\multicolumn{2}{|c|}{\begin{tabular}{|cc|}
\multicolumn{2}{|c|}{$\begin{array}{c}\text { Kieliryhmä } \\
(\mathrm{n}=3945)\end{array}$} \\
Suomen- & Ruotsin- \\
kieliset & kieliset \\
$\%$ & $\%$ \\
\end{tabular}}} & \multicolumn{2}{|c|}{$\begin{array}{l}\text { Sukupuoli } \\
(\mathrm{n}=3945)\end{array}$} & \multicolumn{2}{|c|}{$\begin{array}{c}\text { Maakunta } \\
(\mathrm{n}=3945)\end{array}$} & \multicolumn{3}{|c|}{ Työttömyys / pakkoloma $(\mathrm{n}=3931)$} \\
\hline & & & & $\begin{array}{c}\text { Tytöt } \\
\\
\% \\
\end{array}$ & $\begin{array}{c}\text { Pojat } \\
\% \\
\end{array}$ & Uusimaa & Pohjanmaa & $\begin{array}{c}\text { Ei kumpikaan } \\
\text { vanhemmista } \\
\%\end{array}$ & $\begin{array}{c}\text { Toinen } \\
\text { vanhemmist } \\
\%\end{array}$ & $\begin{array}{c}\text { Molemmat } \\
\text { vanhemmat } \\
\% \\
\end{array}$ \\
\hline $\begin{array}{l}\text { Ei / } \\
\text { Lievä }\end{array}$ & 89 & 89 & 90 & 87 & 92 & 88 & 90 & 91 & 86 & 77 \\
\hline $\begin{array}{l}\text { Keskivaikea / } \\
\text { Vaikea }\end{array}$ & 11 & 11 & 10 & 13 & 8 & 12 & 10 & 9 & 14 & 23 \\
\hline Yhteensä & 100 & 100 & 100 & 100 & 100 & 100 & 100 & 100 & 100 & 100 \\
\hline $\mathrm{N}$ & 3945 & 2130 & 1815 & 2253 & 1692 & 1879 & 2066 & 2964 & 868 & 99 \\
\hline p-arvo & & \multicolumn{2}{|c|}{$\begin{array}{c}0,065 \\
\text { (Kieliryhmien } \\
\text { välillä) }\end{array}$} & \multicolumn{2}{|c|}{$\begin{array}{c}<0,001 \\
\text { (Sukupuolten } \\
\text { välillä) }\end{array}$} & \multicolumn{2}{|c|}{$\begin{array}{c}0,044 \\
\text { (Maakuntien } \\
\text { välillä) }\end{array}$} & \multicolumn{3}{|c|}{ (Työttömyys / pakkolomaryhmien välillä) } \\
\hline
\end{tabular}


Taulukko 2. Lukiolaisten keskivaikean tai vaikean masentuneisuuden yhteydet maakunnittain (OR ja 95 \%:n luottamusväli) sukupuoleen, kieliryhmään ja vanhempien työllisyystilanteeseen. THL:n Kouluterveyskysely 2010/2011. Logistinen regressioanalyysi.

\begin{tabular}{|c|c|c|c|c|}
\hline Taustamuuttuja & $\mathrm{n}$ & $\begin{array}{c}\text { Ristitulosuhde } \\
\text { OR }\end{array}$ & $\begin{array}{c}95 \%: n \\
\text { Luottamusväli lv }\end{array}$ & $\begin{array}{c}\text { Merkitsevyys } \\
\text { p-arvo }\end{array}$ \\
\hline \multicolumn{5}{|c|}{ POHJANMAAN LUKIOT } \\
\hline \multicolumn{5}{|l|}{ Sukupuoli } \\
\hline Pojat & 863 & 1,00 & & \\
\hline Tytöt & 1196 & 1,96 & $1,42-2,71$ & $<0,001$ \\
\hline \multicolumn{5}{|l|}{ Kieliryhmä } \\
\hline Suomenkieliset & 941 & 1,00 & & \\
\hline Ruotsinkieliset & 1118 & 1,19 & $0,88-1,60$ & ns \\
\hline $\begin{array}{l}\text { Vanhempien } \\
\text { työttömyys / pakkoloma } \\
\text { Ei kumpikaan }\end{array}$ & \multicolumn{4}{|c|}{ työttömyys / pakkoloma } \\
\hline Vanhemmista & 1632 & 1,00 & & \\
\hline Toinen vanhemmista & 390 & 1,79 & $1,28-2,51$ & 0,001 \\
\hline Molemmat vanhemmat & 37 & 3,84 & $1,75-8,40$ & 0,001 \\
\hline \multicolumn{5}{|l|}{ UUDENMAAN LUKIOT } \\
\hline \multicolumn{5}{|l|}{ Sukupuoli } \\
\hline Pojat & 820 & 1,00 & & \\
\hline Tytöt & 1052 & 1,76 & $1,30-2,38$ & $<0,001$ \\
\hline \multicolumn{5}{|l|}{ Kieliryhmä } \\
\hline Ruotsinkieliset & 691 & 1,00 & & \\
\hline Suomenkieliset & 1181 & 1,67 & $1,21-2,28$ & 0,002 \\
\hline \multicolumn{5}{|l|}{$\begin{array}{l}\text { Vanhempien } \\
\text { työttömyys / pakkoloma } \\
\text { Ei kumpikaan }\end{array}$} \\
\hline Vanhemmista & 1332 & 1,00 & & \\
\hline Toinen vanhemmista & 478 & 1,36 & $0,99-1,86$ & ns \\
\hline Molemmat vanhemmat & 62 & 2,59 & $1,38-4,85$ & 0,003 \\
\hline
\end{tabular}

Referenssiryhmä on merkitty arvolla 1,00

Keskivaikea tai vaikea masentuneisuus oli yleisintä niillä lukiolaisilla, joiden molemmat vanhemmat olivat olleet työttömänä tai pakkolomalla. Heistä lähes joka neljäs oli kokenut keskivaikeaa tai vaikeaa masentuneisuutta. Vastaava osuus lukiolaisista, joiden vanhemmista vain toinen oli ollut työttömänä tai pakkolomalla oli $14 \%$. Lukiolaisista, joiden vanhemmista kumpikaan ei ollut ollut työttömänä tai pakkolomalla $9 \%$ koki masentuneisuutta $(\mathrm{p}<0,001)$. (Taulukko 1.)

Uudenmaan suomenkielisten lukioiden opiskelijoilla masentuneisuus oli yli puolitoista kertaa todennäköisempää kuin ruotsinkielisillä lukiolaisilla ( $\mathrm{OR}=1,67 ; \mathrm{lv}=1,21-2,28)$. Pohjanmaalla kieliryhmien välistä eroa ei ollut masentuneisuuden todennäköisyydessä. (Taulukko 2.)

Pohjanmaalla toisen vanhemman työttömyydellä tai pakkolomalla oli yhteys nuoren todennäköisyyteen kokea masentuneisuutta $(\mathrm{OR}=$ $1,79 ; \mathrm{lv}=1,28-2,51)$. Jos molemmat olivat olleet työttömänä tai pakkolomalla todennäköisyys kokea masentuneisuutta oli lähes nelinkertainen $(\mathrm{OR}=3,84 ; \mathrm{lv}=1,75-8,40)$ verrattaessa lukiolaisiin, joiden vanhemmat eivät olleet joutuneet työttömäksi tai pakkolomalle. Uudellamaalla ainoastaan molempien vanhempien työttömyys tai pakkoloma lisäsi lukiolaisten keskivaikean 
Taulukko 3. Lukiolaisten keskivaikean tai vaikean masentuneisuuden yhteydet kieliryhmittäin (OR ja $95 \%$ :n luottamusväli) sukupuoleen, makuntaan ja vanhempien työllisyystilanteeseen. THL:n Kouluterveyskysely 2010/2011. Logistinen regressioanalyysi.

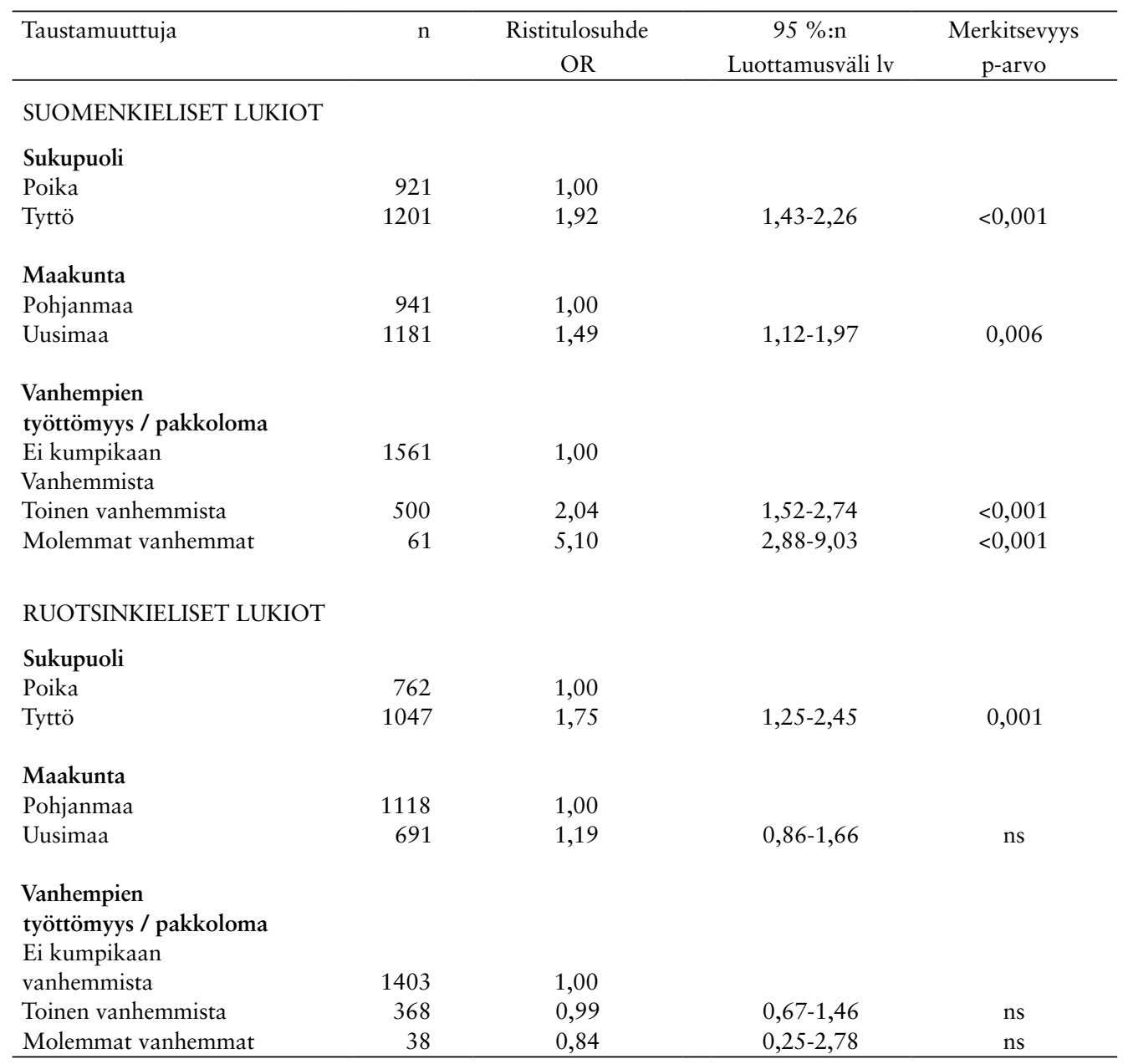

Referenssiryhmä on merkitty arvolla 1,00

tai vaikean masentuneisuuden riskiä yli 2,5-kertaiseksi $(\mathrm{OR}=2,59 ; \mathrm{lv}=1,38-4,85)$ verrattaessa lukiolaisiin, joiden vanhemmat eivät olleet joutuneet työttömäksi tai pakkolomalle. (Taulukko 2.)

Kun lukiolaisia tarkasteltiin kieliryhmittäin, kävi ilmi, että sekä suomenkielisten että ruotsinkielisten lukioiden tytöillä masentuneisuus oli lähes kaksi kertaa todennäköisempää kuin pojilla (suomenkieliset lukiot $\mathrm{OR}=1,92 ; \mathrm{lv}=1,43-2,26$, ruotsinkieliset lukiot $\mathrm{OR}=1,75 ; \mathrm{lv}=1,25-2,45$ ). Maakunta, jossa lukio sijaitsee, oli yhteydessä keskivaikean tai vaikean masentuneisuuden riskiin vain suomenkielisten lukioiden opiskelijoilla. Uudenmaan suomenkielisten lukioiden opiskelijoilla masentuneisuus oli puolitoista kertaa todennäköisempää kuin Pohjanmaan suomenkielisten lukioiden opiskelijoilla $(\mathrm{OR}=1,49$; $\mathrm{lv}=$ 1,12-1,97). (Taulukko 3.)

Vanhempien viimeksi kuluneen vuoden aikainen työttömyys tai pakkoloma lisäsi vain suomenkielisten lukioiden opiskelijoiden riskiä kokea keskivaikeaa tai vaikeaa masentuneisuutta. Masentuneisuuden todennäköisyys oli kaksinkertainen $(\mathrm{OR}=2,04 ; 1,52-2,74)$, jos toinen vanhemmista oli ollut työttömänä tai pakkolomalla, ja yli viisinkertainen, jos molemmat olivat olleet työttömänä tai pakkolomalla $(\mathrm{OR}=5,10 ; \mathrm{lv}=$ 2,88-9,03). Sen sijaan ruotsinkielisten lukioiden opiskelijoilla tätä yhteyttä ei ollut. (Taulukko 3.) 
Taulukko 4. Lukiolaisten keskivaikean tai vaikean masentuneisuuden esiintyvyys kieliryhmittäin ja sukupuolittain maakunnan ja vanhempien työllisyystilanteen mukaan, \%. THL: n Kouluterveyskysely 2010/2011.

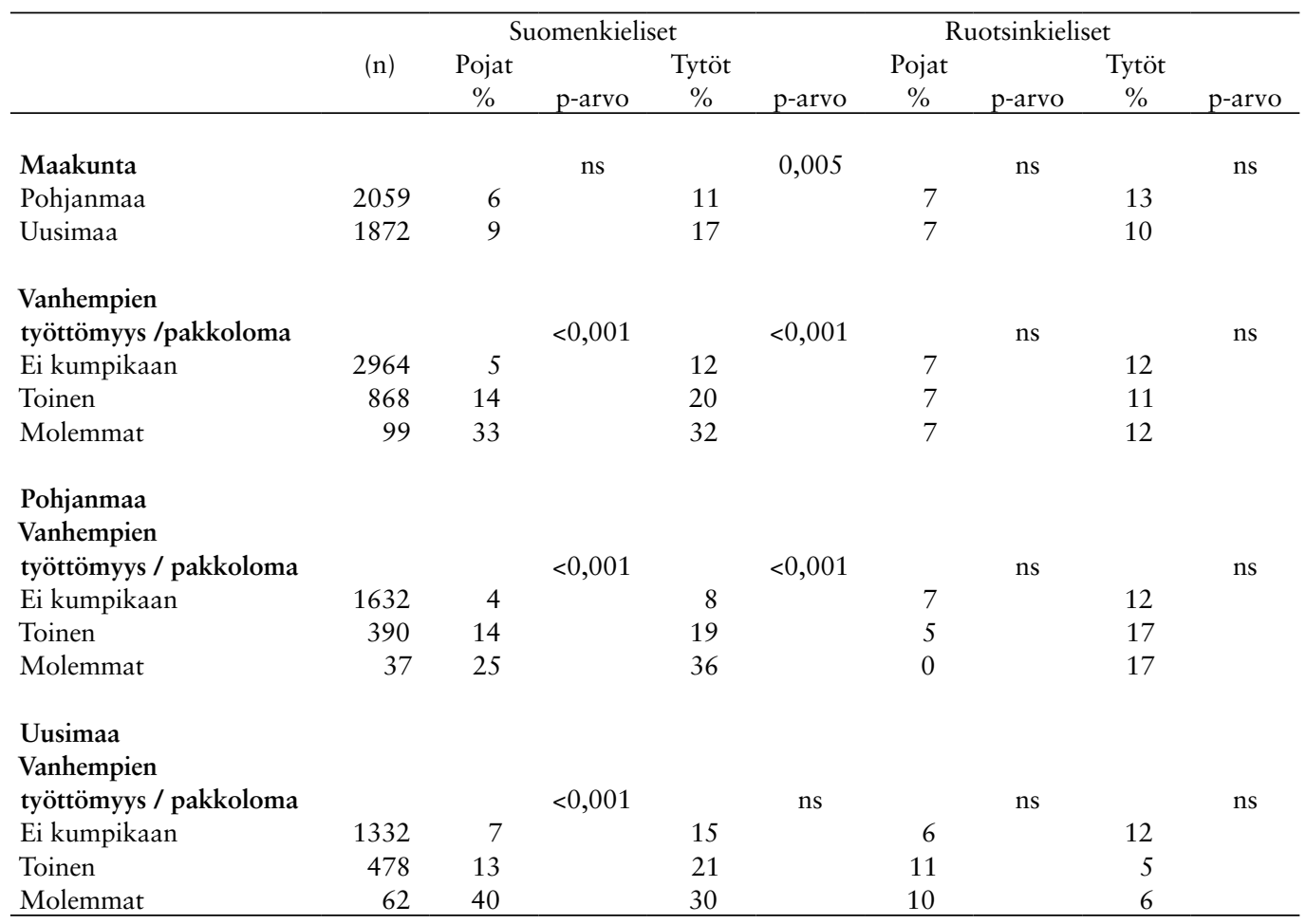

\section{MASENTUNEISUUDEN ESIINTYYYYS KIELIRYHMITTÄIN JA SUKUPUOLITTAIN MAAKUNNAN JA VANHEMPIEN TYÖLLISYYSTILANTEEN MUKAAN}

Suomenkielisten lukioiden opiskelijoilla vanhempien työttömyys tai pakkoloma oli yhteydessä masentuneisuuteen sekä tytöillä että pojilla. Ruotsinkielisten lukioiden opiskelijoilla tällaista vaihtelua ei ollut. Suomenkielisten lukioiden pojista, joiden molemmat vanhemmat olivat olleet työttömänä tai pakkolomalla joka kolmas koki keskivaikeaa tai vaikeaa masentuneisuutta. Vastaava osuus pojista, joiden vanhemmista vain toinen oli ollut työttömänä tai pakkolomalla oli $14 \%$. Suomenkielisten lukioiden pojista, joiden vanhemmista kumpikaan ei ollut ollut työttömänä tai pakkolomalla $5 \%$ koki keskivaikeaa tai vaikeaa masentuneisuutta $(\mathrm{p}<0,001)$. Myös suomenkielisten lukioiden tytöistä, joiden molemmat vanhemmat olivat olleet työttömänä tai pakkolomalla noin joka kolmas koki keskivaikeaa tai vaikeaa masentuneisuutta. Keskivaikeaa tai vai- keaa masentuneisuutta koki viidennes tytöistä, joiden vanhemmista toinen oli ollut työttömänä tai pakkolomalla. Vastaava osuus lukiolaistytöistä, joiden vanhemmista kumpikaan ei ollut ollut työttömänä tai pakkolomalla oli $12 \%(\mathrm{p}<0,001)$. (Taulukko 4.)

Maakunnittainen tarkastelu osoitti, että Pohjanmaalla vanhempien viimeksi kuluneen vuoden aikainen työttömyys tai pakkoloma oli yhteydessä masentuneisuuteen sekä suomenkielisten lukioiden pojilla että tytöillä. Pohjanmaan suomenkielisten lukioiden pojista, joiden molemmat vanhemmat olivat olleet työttömänä tai pakkolomalla joka neljäs koki keskivaikeaa tai vaikeaa masentuneisuutta. Vastaava osuus pojista, joiden vanhemmista vain toinen oli ollut työttömänä tai pakkolomalla oli $14 \%$. Pohjanmaan suomenkielisten lukioiden pojista, joiden vanhemmista kumpikaan ei ollut ollut työttömänä tai pakkolomalla $4 \%$ koki keskivaikeaa tai vaikeaa masentuneisuutta $(\mathrm{p}<0,001)$. (Taulukko 4.) 
Pohjanmaan suomenkielisten lukioiden tytöistä, joiden molemmat vanhemmat olivat olleet työttömänä tai pakkolomalla yli kolmannes koki keskivaikeaa tai vaikeaa masentuneisuutta. Vastaavasti lukiolaistytöistä, joiden vanhemmista kumpikaan ei ollut ollut työttömänä tai pakkolomalla $8 \%$ koki keskivaikeaa tai vaikeaa masentuneisuutta $(\mathrm{p}<0,001)$. (Taulukko 4.)

Uudellamaalla vanhempien viimeksi kuluneen vuoden aikainen työttömyys tai pakkoloma oli yhteydessä keskivaikeaan tai vaikeaan masentuneisuuteen vain suomenkielisten lukioiden pojilla: Jos molemmat vanhemmat olivat olleet työttömänä tai pakkolomalla, $40 \%$ koki keskivaikeaa tai vaikeaa masentuneisuutta. Vastaavasti lukiolaispojista, joiden vanhemmista kumpikaan ei ollut ollut työttömänä tai pakkolomalla $7 \%$ koki keskivaikeaa tai vaikeaa masentuneisuutta $(\mathrm{p}<0,001)$. (Taulukko 4.)

\section{POHDINTA}

Tutkimuksen päätulos on, että suomenkielisten ja ruotsinkielisten lukioiden opiskelijoilla masentuneisuuden esiintyvyys oli erilaista, kun sitä tarkasteltiin vanhempien työllisyystilanteen suhteen. Suomenkielisten lukioiden opiskelijoilla vanhempien työttömyys tai pakkoloma lisäsivät huomattavan paljon keskivaikean tai vaikean masentuneisuuden riskiä. Sen sijaan ruotsinkielisten lukioiden opiskelijoilla vanhempien työttömyys tai pakkoloma ei ollut yhteydessä keskivaikean tai vaikean masentuneisuuden riskiin.

Uudenmaan ja Pohjanmaan lukiolaisista hieman useammalla kuin joka kymmenennellä (11\%) oli keskivaikeaa tai vaikeaa masentuneisuutta. Luku vastaa hyvin Kouluterveyskyselyn valtakunnallista tulosta masentuneisuuden esiintyvyydestä: vuosina 2010 ja 2011 suomalaisista lukiolaisista $10 \%$ :lla oli keskivaikeaa tai vaikeaa masentuneisuutta (29). Vuosien 2007 ja 2008 Kouluterveysaineistoon pohjautuvassa Uudenmaan ja Pohjanmaan lukiolaisia tarkastelevassa tutkimuksessa, jonka aineistoon oli valittu samat kunnat kuin tässä tutkimuksessa, keskivaikean tai vaikean masentuneisuuden esiintyvyys oli myös $11 \%$ (15).

Tässä tutkimuksessa lukiolaisten keskivaikea tai vaikea masentuneisuus oli hieman yleisempää Uudellamaalla kuin Pohjanmaalla. Myös aikuisväestöä tarkastelevan tutkimuksen mukaan 20-54-vuotiailla suomalaisilla masennusoireilu oli vähän yleisempää Uudellamaalla kuin Pohjanmaalla vuonna 2013 (43). Sen sijaan vuosien 2007 ja 2008 Kouluterveyskyselyyn perustuvassa tutkimuksessa ei ilmennyt eroa lukiolaisten masentuneisuuden esiintyvyydessä Uudenmaan ja Pohjanmaan välillä (15). Tämän tutkimuksen mukaan lukion sijaintimaakunta oli yhteydessä keskivaikean tai vaikean masentuneisuuden riskiin vain suomenkielisillä. Uudenmaan suomenkielisten lukioiden opiskelijoilla masentuneisuus oli selvästi yleisempää kuin Pohjanmaan suomenkielisten lukioiden opiskelijoilla. Ruotsinkielisten lukioiden opiskelijoilla ei ilmennyt maakuntien välistä eroa masentuneisuuden todennäköisyydessä.

Kuten monissa muissa nuorten masennusta ja masentuneisuutta tarkastelevissa tutkimuksissa $(44,45,46,24)$, myös tässä tutkimuksessa tytöillä keskivaikea tai vaikea masentuneisuus oli selvästi yleisempää kuin pojilla. Tämä sukupuolten välinen ero masentuneisuuden esiintyvyydessä ilmeni kummassakin kieliryhmissä ja molemmissa maakunnissa.

Koko aineistoa tarkasteltaessa suomenkielisten ja ruotsinkielisten lukioiden opiskelijoiden välillä ei ilmennyt eroa lukiolaisten masentuneisuudessa. Maakunnittain voitiin kuitenkin löytää kieliryhmittäisiä eroja: Uudenmaan suomenkielisten lukioiden opiskelijoilla masentuneisuus oli yli puolitoista kertaa todennäköisempää kuin Uudenmaan ruotsinkielisten lukioiden opiskelijoilla. Pohjanmaalla sen sijaan lukiolaisten keskivaikea tai vaikea masentuneisuus oli yhtä todennäköistä molemmissa kieliryhmissä. Myös Uudenmaan ja Pohjanmaan kuntien Kouluterveyskyselyyn (vuodet 2007 ja 2008) perustuvassa tutkimuksessa ilmeni, että kieliryhmittäiset erot tulevat esiin vain Uudellamaalla, jossa keskivaikea tai vaikea masentuneisuus on suomenkielisten lukioiden opiskelijoilla yleisempää kuin ruotsinkielisten lukioiden opiskelijoilla (15).

Hyypän ja Mäen $(3,4)$ tutkimusten mukaan Pohjanmaan ruotsinkielisen väestön terveys oli parempi kuin maakunnan suomenkielisen väestön. Eroja selitettiin Pohjanmaan ruotsinkielisen väestön kulttuurin ja heidän sosiaalisen pääomansa kautta. Tämän tutkimuksen tulos ei kuitenkaan lukiolaisten masentuneisuuden osalta tue Hyypän ja Mäen $(3,4)$ tulosta, koska tässä tutkimuksessa Pohjanmaan lukiolaisilla masen- 
tuneisuus oli yhtä yleistä kummassakin kieliryhmässä. Myös Saarelan ja Finnäsin (14) tutkimus osoitti, että Pohjanmaalla nuorten itsearvioidussa terveydessä kieliryhmien välillä ei ilmennyt eroja. Tämän tutkimuksen tulos Pohjanmaan lukiolaisten masentuneisuuden kieliryhmien välisistä eroista on samansuuntainen Saarelan ja Finnäsin (14) tutkimustuloksen kanssa nuorten itsearvioidun terveyden osalta. Sen sijaan Uudellamaalla suomenkieliset lukiolaiset kokivat tämän tutkimuksen mukaan masentuneisuutta ruotsinkielisiä yleisemmin.

Mistä johtuu, että Uudellamaalla ruotsinkielisten lukioiden opiskelijat erottuvat suomenkielisten lukioiden opiskelijoista selvästi vähemmän masentuneena ryhmänä, mutta Pohjanmaalla masentuneisuus on ruotsinkielisillä lukiolaisilla yhtä yleistä kuin suomenkielisillä?

Tutkimukseen osallistuneissa Pohjanmaan kaksikielisissä kunnissa ruotsinkielisten asukkaiden osuus oli vuonna 2010 keskimäärin hieman suurempi kuin Uudenmaan kaksikielisissä kunnissa (47). Uudellamaalla ruotsinkieliset ovat siis selvemmin vähemmistöasemassa kuin Pohjanmaalla. Voidaankin pohtia, onko Uudenmaan ruotsinkielisillä lukiolaisilla vähemmistöaseman aikaansaama tunne yhteisöllisyydestä ja sosiaalisesta kiinteydestä vahvempi kuin Pohjanmaan ruotsinkielisillä lukiolaisilla.

Tässä tutkimuksessa ilmeni, että keskivaikea tai vaikea masentuneisuus oli yleisintä niillä $\mathrm{Uu}$ denmaan ja Pohjanmaan lukiolaisilla, joiden molemmat vanhemmat olivat olleet työttömänä tai pakkolomalla viimeksi kuluneen vuoden aikana. Lukiolaisista, joiden molemmat vanhemmat olivat olleet työttömänä tai pakkolomalla lähes joka neljäs oli kokenut keskivaikeaa tai vaikeaa masentuneisuutta. Tutkimustulos on samansuuntainen aikaisempien tutkimusten kanssa, joissa perheen alhaisen sosioekonomisen aseman, on todettu lisäävän lasten ja nuorten psyykkistä pahoinvointia $(18,19)$ ja masentuneisuutta $(20$, 21). Tässä tutkimuksessa tuli kuitenkin esiin, että erot lukiolaisten keskivaikean tai vaikean masentuneisuuden esiintyvyydessä vanhempien työttömyyden tai pakkoloman suhteen ilmenivät ainoastaan suomenkielisillä. Suomenkielisten lukioiden opiskelijoilla, joiden molemmat vanhemmat olivat olleet työttömänä tai pakkolomalla, keskivaikean tai vaikean masennuksen riski oli yli viisinkertainen verrattuna suomenkielisten lukioiden opiskelijoihin, joiden vanhemmat eivät olleet joutuneet työttömäksi tai pakkolomalle. Ruotsinkielisillä vanhempien työttömyys tai pakkoloma ei ollut yhteydessä lukiolaisten masentuneisuuden todennäköisyyteen. Suomenkielisillä lukiolaisilla masentuneisuuden erot vanhempien työttömyyden tai pakkolomien suhteen ilmenivät sekä Uudellamaalla (suomenkieliset pojat) että Pohjanmaalla (suomenkieliset tytöt ja pojat).

Pohdittavaksi nousee, miksi suomenkielisen ja ruotsinkielisen kieliryhmän välillä on eroja tarkasteltaessa lukiolaisten masentuneisuutta vanhempien työttömyyden tai pakkolomien suhteen. Suomenkielisten lukioiden opiskelijoilla vanhempien työttömyys tai pakkoloma lisäsivät huomattavan paljon keskivaikean tai vaikean masentuneisuuden riskiä, kun taas ruotsinkielisten lukioiden opiskelijoilla vanhempien työttömyydellä tai pakkolomalla ei ollut yhteyttä keskivaikean tai vaikean masentuneisuuden riskiin. Sekä Uudellamaalla että Pohjanmaalla ruotsinkieliset asukkaat ovat suomenkielisiä yleisemmin lähtöisin alueelta, jossa he asuvat. Sen sijaan suomenkielisille on ruotsinkielisiä tavallisempaa se, että he ovat muuttaneet alueelle muualta Suomesta. $(7,48)$ Muualta muuttaneiden terveys on keskimäärin heikompi kuin natiiviasukkaiden (7). Terveyteen ja hyvinvointiin voi vaikuttaa esimerkiksi se, että muualta muuttaneet ovat vähemmän integroituneita yhteisöön, mikä voi johtaa vieraantumisen tunteisiin ja eristäytyneisyyteen (7). Ovatko vahvempi integroituminen yhteisöön ja samalla alueella asuvat sukulaiset tekijöitä, jotka suojaavat ruotsinkielisiä lukiolaisia masentuneisuudelta heidän vanhempiensa joutuessa työttömiksi tai pakkolomalle? On mahdollista, että yhteisön tuki suojaa vanhempia psyykkiseltä kuormittuneisuudelta työttömyyden aikana, jolloin perheen vaikeudet eivät heijastu lasten ja nuorten elämään mielenterveysongelmina. Ruotsinkieliselle kieliryhmälle ominaista yhteisöllisyyttä, luottamusta toisiin ihmisiin ja sosiaalista vuorovaikutusta (sosiaalista pääomaa) onkin pidetty hyvän terveyden perustana useissa tutkimuksissa. $(3,4)$

Saarelan (48) tutkimuksen mukaan myös taloudellinen elintaso oli korkeampi natiiviasukkailla kuin muualta muuttaneillla. Taloudellinen elintaso oli ruotsinkielisillä suomenkielisiä korkeampi sekä Uudellamaalla että Pohjanmaalla. (48) Eroa suomenkielisten ja ruotsinkielisten 
lukiolaisten masentuneisuudessa vanhempien joutuessa työttömäksi voidaan siis pohtia myös taloudellisten tekijöiden kautta. Suojaako ruotsinkielisten perheiden parempi toimeentulo lukiolaisia masentuneisuudelta vanhempien joutuessa työttömiksi?

Nämä tutkimustulokset avaavat monia uusia suuntia jatkotutkimukselle. Kiinnostavaa olisi esimerkiksi selvittää Suomen sisällä tapahtuvan muuttoliikkeen merkitystä perheiden hyvinvointiin. Suojaavatko samalla alueella asuva suku ja yhteisöllisyys lapsia ja nuoria mielenterveysongelmilta perheiden kriisitilanteissa? Mielenkiintoista olisi myös tarkastella, kuinka paljon tämän tutkimuksen päätulosta voitaisiin selittää perheiden taloudellisten resurssien kautta. Selittäisikö ruotsinkielisten perheiden parempi taloudellinen toimeentulo sitä, miksi vanhempien työttömyys ei aiheuta ruotsinkielisille lukiolaisille masentuneisuutta.

\section{TUTKIMUKSEN LUOTETTAVUUS}

THL:n Kouluterveyskysely on kokonaistutkimus. Kyselylomakkeessa ilmoitetaan, että kyselyyn vastaaminen perustuu vapaaehtoisuuteen. (29) Tutkimuksen luotettavuuden kannalta olisi tärkeää selvittää tarkasti kadon suuruus ja se, millaisiin lukiolaisryhmiin kato kohdistuu. Tässä tutkimuksessa näitä tietoja ei ole käytettävissä. Tutkimuksessa on tärkeätä pohtia Kouluterveyskyselyn luotettavuutta masentuneisuuden vaikeusasteiden esiintyvyyttä tarkastelevana tutkimuksena. On mahdollista, että vastaajissa tapahtuu valikoitumista siten, että useat vaikeaa masentuneisuutta kokevat opiskelijat ovat masentuneisuuden vuoksi pois koulusta, eivätkä siten vastaa kyselyyn. Jos kato kohdistuu muita masentuneisuuden vaikeusasteita enemmän vaikean masentuneisuuden pistemäärän saaneisiin opiskelijoihin, se aiheuttaa tutkimustuloksiin systemaattista vääristymää, koska tällöin keskivaikeaa tai vaikeaa masentuneisuutta kokevien lukiolaisten ryhmään kuuluvien osuus on tuloksissa todellista pienempi.

Kouluterveyskysely perustuu opiskelijoiden itsearviointiin. Opiskelijat arvioivat hyvinvointiaan erilaisten masentuneisuuteen liittyvien väittämien kautta. Itsearviointiin perustuvana mittarina kyselyn luotettavuutta lisää se, että kysymykset on muotoiltu selkeiksi ja niissä on vältetty liiallista abstraktisuutta, joten nuoret pysty- vät ymmärtämään kysymykset helposti. Yleisesti ottaen nuorten terveyden ja oireilun itsearviointiin perustuvien mittareiden on osoitettu olevan luotettavia. Norjalaisen tutkimuksen mukaan nuoret pystyvät arvioimaan totuudenmukaisesti omaa terveyttään ja oireiluaan. Heidän tutkimuksessaan ilmeni kuitenkin pieniä sukupuolten välisiä eroja: tyttöjen arviot omasta terveydestä osoittautuivat poikien arvioita luotettavimmiksi (38).

Myös masentuneisuuden arvioinnissa itsearviointiin perustuvat mittarit ovat osoittautuneet luotettaviksi. Kouluterveyskyselyssä masentuneisuutta mitattiin masentuneisuuden itsearviointiin perustuvan Beckin lyhyemmän mielialakyselyn avulla. Aikaisemmissa tutkimuksissa sekä alkuperäisen Beckin pidemmän mielialakyselyn (34, 39) että lyhyen mielialakyselyn (35) reliabiliteetti ja validiteetti ovat osoittautuneet hyviksi. Kouluterveyskyselyssä Beckin lyhyt mielialakysely on Raitasalon muokkaamana suomalaisena versiona, jonka validiteetin ja reliabiliteetin on osoitettu olevan hyvä $(30,31,40,32,33,41)$. Myös Beckin mielialakyselyn suomalainen versio on soveltuva mittari nuoruusikäisen väestön masentuneisuuden mittaamiseen $(40,32)$.

Tässä tutkimuksessa Beckin mielialakyselyyn perustuvan masentuneisuussummamuuttujan reliabiliteettia mitattiin Cronbachin alfan kertoimella, joka oli 0,85 . Tämä osoittaa hyvää reliabiliteettia.

Masennus- (depressio-), masentuneisuus- ja masennusoireilukäsitteiden erottelu muodostaa haasteen tämän tutkimuksen validiteetille. Eri tutkimuksissa masennus- ja masentuneisuuskäsitteitä käytetään eri tavoin ja eri merkityksissä, eikä täysin vakiintunutta erottelua näiden käsitteiden välillä voida löytää. Käsitteiden vaihteleva ja päällekkäinen käyttö eri tutkimuksissa vaikeuttaa tutkimuksen tulosten vertailua aikaisempiin tutkimuksiin.

Terveyteen ja erityisesti mielenterveyteen liittyvät asiat koetaan usein arkaluontoisina ja henkilökohtaisina, minkä vuoksi myös tämän tutkimuksen nuorten masentuneisuuteen liittyvä aihe on arkaluontoinen. Myös vastaajien alaikäisyys asettaa haasteita aineistonkeruun eettisyydelle. Kuula (42) kuitenkin painottaa, että marginaalisia ihmisryhmiä, esimerkiksi alaikäisiä lapsia ja nuoria, ei saisi sulkea pois tutkimuksen piiristä, jotta ihmiselämästä ei jäisi tutkimatta olen- 
naisia puolia. Lasten ja nuorten osallistuminen tutkimuksiin on perusteltua sekä kulttuurin, yhteiskunnan ja lääketieteen tutkimuksen näkökulmasta että lasten ja nuorten itsensä näkökulmasta. Alaikäisille lapsille ja nuorille pitää antaa oikeus tulla kuulluksi omilla ehdoillaan. On siis tärkeää, ettei alaikäisten nuorten terveyteen liittyviä asioita jätetä tutkimatta.

\section{KIRJOITTAJIEN KONTRIBUUTIOT:}

EK toteutti artikkeliin sisältyvien tilastollisten analyysien tekemisen ja artikkelin käsikirjoituksen sekä tiivistelmien kirjoittamisen. JT ja RV osallistuivat artikkelin ohjaukseen ja kommentointiin. HK osallistui artikkelin aineistonkeruuseen sekä artikkelitekstin kommentointiin.

Kangas E, Tynjälä J, Välimaa R, Kivimäki H. Depressive symptoms among upper secondary school students and parental employment status - Comparisons between the Finnish and Swedish-speaking upper secondary school students in Uusimaa and Ostrobothnia. Sosiaalilääketieteellinen aikakauslehti - Journal of Social Medicine 2017:54: 90-103

In Finland, the welfare differences among different demographic groups are large. Research has reported, for example, welfare differences among regional, socio-economic groups and among Finnish- and Swedish-speaking groups. These differences are apparent also in health and welfare of children and youth.

The aim of the study was to analyse, whether the prevalence of depressiveness varies based on the language of teaching of the Upper Secondary School, gender, municipality and parental employment status. The data originated from the responses of upper secondary school students $(n=3974)$ to the School Health Promotion Study (National Institute for Health and Welfare) in the years 2010 and 2011 in Uusimaa and Ostrobothnia. Depressive symptoms were measured using the Finnish version of Beck Depression Inventory included in the School Health Promotion Study, which measures self-reported mental condition.

In Uusimaa and Ostrobothnia $11 \%$ of the students reported moderate or severe depressive symptoms. The difference in the prevalence of depressiveness among language groups was evident only in Uusimaa, where depressive symptoms were more common among Finnish-speaking students than among Swedish-speaking.

\section{LÄHTEET}

(1) Karvonen S, Kauppinen T. Kuinka Suomi jakautuu 2000-luvulla? Hyvinvoinnin muuttuvat alue-erot. Yhteiskuntapolitiikka 2009;74: 467-486.

(2) Martelin T, Koskinen S, Valkonen T. Kuolleisuus. Kirjassa: Aromaa A, Huttunen J, Koskinen S, Teperi J. (toim.) Suomalaisten terveys. Helsinki: Duodecim; 2005, 117-129.

(3) Hyyppä M. T, Mäki J. Individual-Level
A key finding was that among Finnish-speaking students, parental unemployment or temporary dismissal increased substantially the risk of moderate or severe depressive symptoms. If one of the parents was unemployed or furloughed, the probability of depressive symptoms was twice as high (Odds ratio $=2,04 ; 95 \%$ Confidence interval 1,52-2,74), and if both parents were unemployed or furloughed, the probability of depressive symptoms was more than five times as high (Odds ratio $=5,10 ; 95 \%$ Confidence interval 2,88-9,03) compared to students whose parents were employed. Among Swedish-speaking students, parental unemployment was not associated with the risk of moderate or severe depressive symptoms.

It can be further scrutinized, why there are differences among the language groups in terms of the relationship between students' depressiveness and parental employment status. Could this difference be explained, for example, through the impacts of migration or through the economic livelihoods of the families.

Keywords: Upper secondary school students, depressive symptoms, linguistic groups, parental employment status

Relationships between Social Capital and SelfRated Health in a Bilingual Community. Prev Med 2001a;32:148-155. https://doi.org/10.1006/pmed.2000.0782

(4) Hyyppä MT, Mäki J. Why do Swedish-speaking Finns have longer active life? An area for social capital research. Health Promot Int 2001b;16:55-64. https://doi.org/10.1093/heapro/16.1.55 
(5) Nyqvist F, Finnäs F, Jakobsson G, ym. The effect of social capital on health: The case of two language groups in Finland. Health Place 2008; 14:347-360.

https://doi.org/10.1016/j. healthplace.2007.09.001

(6) Riihinen O. Teollistuvan yhteiskunnan alueellinen erilaistuneisuus. Kuopio: WSOY; 1965.

(7) Saarela J, Finnäs F. Regional Mortality Variation in Finland: A Study of Two Population groups. Genus 2006; 62: 169-211.

(8) Saarela J, Finnäs, F. Cause-specific Mortality at young Ages: Lessons from Finland. Health $\&$ Place 2008; 14: 265-274. https://doi.org/10.1016/j. healthplace.2007.06.007

(9) Lönnqvist J, Henriksson M, Isometsä E, Marttunen M. Itsetuhokäyttäytyminen. Teoksessa Lönnqvist J, Henriksson M, Marttunen M, Partonen T. (Toim.) Psykiatria. Helsinki: Duodecim; 2011: 501-515.

(10) Hyyppä MT. Elinvoimaa yhteisöstä. Sosiaalinen pääoma ja terveys. Keuruu: PS-kustannus; 2002.

(11) McRae K. D. Conflict and Compromise in Multilingual Societies. Finland. Suomalaisen tiedeakatemian toimituksia. Sarja Humaniora 306. Rauma: The Finnish Academy of Science and Letters \& Wilfrid Laurier University Press; 1999.

(12) Välimaa R. Subjektivt upplevt hälsa bland unga. Kirjassa: Kannas L, Brunell V. (toim.) Subjektiv hälsa, hälsovanor och skoltrivsel. Jämförelse mellan svensk- och finskspråkiga elever 1994-1998. Folkhälsan Jyväskylä: Jyväskylän yliopistopaino \& ER-Paino oy; 2000, 11-43.

(13) Suominen SB, Välimaa RS, Tynjälä JA, ym. Minority status and perceived health: a comparative study of Finnish- and Swedishspeaking schoolchildren in Finland. Scand J Public Health 2000;28:179-187. https://doi.org/10.1177/14034948000280030601

(14) Saarela JM, Finnäs FSA. The health of Swedishspeaking and Finnish-speaking schoolchildren in Finland. Child Care Health Dev 2003;30:51-58. https://doi.org/10.1111/j.13652214.2004.00385.x

(15) Kangas E. Lukiolaisten masentuneisuus, koettu avuntarve, tyytyväisyys opiskeluterveydenhuoltoon ja sen käyttö - Uudenmaan ja Pohjanmaan maakuntien, suomen- ja ruotsinkielisten kieliryhmien ja sukupuolten vertailua. Pro gradu -tutkielma. Jyväskylän yliopisto; 2011.

(16) Haldorsson M, Kunst AE, Köhler L, ym. Sosioeconomic inequalities in the health of children and adolescents. A comparative study of the five Nordic Countries. Eur J Public Health 2000;10:281 -288 .

(17) Pedersen CR, Holstein BE, Köhler L. Parent's labour market participation as predictor of childen's well-being: changes from 1984 to 1996 in the Nordic countries. Eur J Public Health 2005;15:431-436. https://doi.org/10.1093/eurpub/cki012
(18) Solantaus T, Leinonen J, Punamäki R-L. Children's Mental Health in Times of Economic Recession: Replication and Extension of the Family Economic Stress Model in Finland. Dev Psychol 2004;40:412-429. https://doi.org/10.1037/0012-1649.40.3.412

(19) Koivusilta LK, Rimpelä AH, Kautiainen SM. Health inequality in adolescence. Does stratification occur by familiar social background, family affluence, or personal social position? BMC Public Health 2006;6:110-124. https://doi.org/10.1186/1471-2458-6-110

(20) Fröjd S, Marttunen M, Pelkonen M, ym. Perceived financial difficulties and maladjustment outcome in adolescence. Eur J Public Health 2006;16:542-548. https://doi.org/10.1093/eurpub/ckl012

(21) Torikka A, Kaltiala-Heino R, Rimpelä A, ym. Self-reported depression is increasing among socio-economically disadvantaged adolescents - repeated cross-sectional surveys from Finland from 2000 to 2011. BMC Public Health 2014; $14: 408$ http://www.biomedcentral.com/14712458/14/408. https://doi.org/10.1186/1471-2458-14-408

(22) Kaltiala-Heino R.-K, Rimpelä M, Rantanen $\mathrm{P}, \mathrm{ym}$. Adolescent depression: the role of discontinuities in fife course and social support. J Affect Disord 2001; 64:155-166. https://doi.org/10.1016/S0165-0327(00)00233-0

(23) Hankin BL, Abramson LY, Moffitt TE, ym. Development of Depression from Preadolescence to Young Adulthood: Emerging Gender Differences in a 10-year Longitudinal Study. J Abnorm Psychol 1998;107:128-140. https://doi.org/10.1037/0021-843X.107.1.128

(24) Luopa P, Kivimäki H, Matikka A, Vilkki S, Jokela J, Laukkarinen E, Paananen R. Nuorten hyvinvointi Suomessa 2000-2013. Kouluterveyskyselyn tulokset. Raportti 25/2014. Helsinki: Terveyden ja hyvinvoinnin laitos; 2014.

(25) Pine DS, Cohen E, Cohen P, ym. Adolescent depressive symptoms as predictors of adolescent depression: moodiness or mood disorder? Am J Psychiatry 1999;156:133-135. https://doi.org/10.1176/ajp.156.1.133

(26) Aalto-Setälä T, Marttunen M, TuulioHenriksson A, ym. Depressive Symptoms in Adolescence as Predictors of any Early Adulthood Depressive Disorders and Maladjustment. Am J Psychiatry 2002;159:1235-1237. https://doi.org/10.1176/appi.ajp.159.7.1235

(27) González-Tejera G, Canino G, Ramírez R, $y m$. Examining minor and major depression in adolescents. J Child Psychol Psychiatry 2005;46:888-899.

https://doi.org/10.1111/j.1469. 7610.2005.00370.x

(28) Sihvola E, Keski-Rahkonen A, Dick DM, ym. Minor depression in adolescence. Phenomenology and clinical correlates. J Affect Disord 2007;97:211-218. https://doi.org/10.1016/j.jad.2006.06.019 
(29) Terveyden ja hyvinvoinnin laitos.

Kouluterveyskysely 2014. Luettu 31.5.2014.

(30) Raitasalo R, Notkola V. Viljelijäväestön mielenterveyden ongelmien seulonta ja työterveyshuolto. Sosiaalilääk Aikak 1987;24:232-241.

(31) Raitasalo R. Elämänhallinta sosiaalipolitiikan tavoitteena. Sosiaali- ja terveysturvan tutkimuksia 1. Helsinki: Kansaneläkelaitos; 1995.

(32) Kaltiala-Heino R-K, Rimpelä M, Rantanen P, ym. Finnish modification of the 13-item Beck Depression Inventory in screening an adolescent population for depressiveness and positive mood. Nord J Psychiatry 1999;53:451-457. https://doi.org/10.1080/080394899427700

(33) Raitasalo R. Mielialakysely. Suomen oloihin Beckin lyhyen depressiokyselyn pohjalta kehitetty masennusoireilun ja itsetunnon kysely. Sosiaali- ja terveysturvan tutkimuksia 86. Helsinki: Kelan tutkimusosasto; 2007.

(34) Beck AT, Ward CH, Mendelson M, ym. An Inventory for Measuring Depression. Arch Gen Psychiatry 1961;4:53-63. https://doi.org/10.1001/ archpsyc.1961.01710120031004

(35) Beck AT, Rial WY, Rickels K. Short form of depression inventory: cross-validation. Psychol Rep 1974;34:1184-1186.

(36) Luopa P, Pietikäinen M, Jokela J. Mistä tukea? Helsinkiläisnuorten masentuneisuus, koulukiusaaminen ja luvattomat poissaolot vuosina 1996-2006. Helsinki: Terve ja turvallinen kaupunki -neuvottelukunta, STAKES; 2006.

(37) Ellonen N. Kasvuyhteys nuoren turvana. Sosiaalisen pääoman yhteys nuorten masentuneisuuteen ja rikekäyttäytymiseen. Tampere: Tampereen yliopisto; 2008.

(38) Haugland S, Wold P. Subjektive health complaints in adolescence - reability and validity of survey methods. J Adolesc 2001;24:611-624. https://doi.org/10.1006/jado.2000.0393

(39) Bumberry W, Oliver JM, McClure JN. Validation of the Beck Depression Inventory in a university population using psychiatric Estimate as the criterion. J Consult Clin Psychol 1978;46:150-155.

https://doi.org/10.1037/0022-006X.46.1.150

(40) Kaltiala-Heino R, Rimpelä M, Rantanen P. School performance and self-reported depressive symptoms in middle adolescence. Psychiatria fennica 1998;29:40-49.

(41) Nuevo R, Lehtinen V, Reyna-Liberato PM, ym. Usefulness of the Beck Depression Inventory as a screening method for depression among the general population of Finland. Scand J Public Health 2009;37:28-34. https://doi.org/10.1177/1403494808097169

(42) Kuula A. Tutkimusetiikka. Aineistojen hankinta, käyttö ja säilytys. Jyväskylä: Vastapaino; 2006.
(43) Terveyden ja hyvinvoinnin laitos. Kaikkonen R, Murto J, Pentala O, Koskela T, Virtala E, Härkänen T, Koskenniemi T, Ahonen J, Vartiainen E, Koskinen S. Alueellisen terveys- ja hyvinvointitutkimuksen perustulokset 20102014. Luettu 27.8.2014

(44) Witthcen HU, Nelson CB, Lachner G. Prevalence of mental disorders and psychosocial impairments in adolescents and young adults. Psychol Med 1998; 28: 109-126. https://doi.org/10.1017/S0033291797005928

(45) Haarasilta L, Marttunen M, Kaprio J, ym. The 12-month prevalence and charasteristics of major depressive episode in a representative nationwide sample of adolescents and young adults. Psychol Med 2001;31:1169-1179. https://doi.org/10.1017/S0033291701004573

(46) Välimaa R. Nuorten itsearvioitu terveys ja toistuva oireilu 1984-2002. Kirjassa: Kannas L. (toim.) Koululaisten terveys ja terveyskäyttäytyminen muutoksessa. WHOkoululaistutkimus 20 vuotta. Jyväskylä: Terveyden edistämisen keskus. Jyväskylän yliopisto. Julkaisuja 2, 2004.

(47) Tilastokeskus. Väestö kielen mukaan sekä ulkomaan kansalaisten määrä ja maa-pinta-ala alueittain 1980 - 2013. Luettu 15.7.2014. http://193.166.171.75/Dialog/varval. asp?ma=060_vaerak_au_107\&ti= V\%E4est\%F6+kielen+mukaan+sek\%E4+ ulkomaan+kansalaisten $+\mathrm{m} \% \mathrm{E} 4 \% \mathrm{E} 4 \mathrm{r} \%$ $\mathrm{E} 4+\mathrm{ja}+\mathrm{maa} \% 2 \mathrm{Dpinta} \% 2 \mathrm{Dala}+$ alueittain+ 1980+\%2D+ 2013\&path=../Database/StatFin/ $\mathrm{vrm} /$ vaerak/\&lang=3\&multilang=fi

(48) Saarela J. Wealth in Two Ethnic Groups: The Role of Internal Migration Background. Finnish Yearbook of Population Research 2006; 42: 43-64.

\section{Elina KangaS \\ FM, TtM \\ Jyväskylän yliopisto \\ Terveystieteiden laitos}

JoRma TYNJÄLÄ

LitT, lehtori

Jyväskylän yliopisto

Terveystieteiden laitos

RAILI VäLIMAA

$T t T$, dosentti, lebtori

Jyväskylän yliopisto

Terveystieteiden laitos
HANNE KIVIMÄKI
$T t M$, th, tutkija
Terveyden ja byvinvoinnin laitos (THL)
Lapset, nuoret ja perheet $-y k s i k k o ̈$,
Hyvinvointi-osasto. 